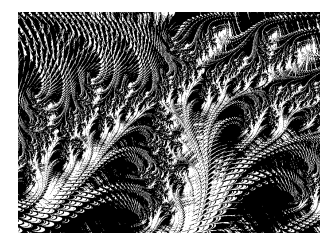

https://doi.org/10.5559/di.30.4.07

\title{
CORRECTIONS PRACTICE IN THE CROATIAN ONLINE MEDIA: BETWEEN LEGISLATION AND TRADITION
}

Mato BRAUTOVIĆ

Department of Mass Communication,

University of Dubrovnik, Dubrovnik, Croatia

UDK: [070.13:004.738.5](497.5)

Preliminary communication

Received: December 16, 2019

Economic, technological and societal trends have switched the model of (online) journalism so that it is focused on the immediacy and volume that has resulted in a lower level of accuracy. To retain a critical function in a democracy, that model needs a corresponding error correction practice. In this study, we used content analysis to investigate how the Croatian online media correct errors, and how their correction practices differ according to the types of online media. The results demonstrate that errors in action or meaning $(N=217)$ were $67.8 \%$ of all errors, that the most common way of correcting errors was by posting an independent note about an error that was linked to the article $(59 \%, N=188)$, and that the correction notes were linked to uncorrected articles in $85.1 \%(N=159)$ of cases. The findings showed that the only statistically significant difference between traditional and online media were the correction labelling practice and the location of the corrections.

Keywords: online journalism, accuracy, error correction, correction practice, Croatia

Mato Brautović, Department of Mass Communication, University of Dubrovnik, Branitelia Dubrovnika 29, 20000 Dubrovnik, Croatia.

E-mail: mbraut@unidu.hr

\section{INTRODUCTION}

Contemporary journalism practice is defined by the structural changes in the media industry, where a smaller number of journalists create more content for multiple platforms. As a result of economic, technological and societal trends, a jour- 
DRUŠ. ISTRAŽ. ZAGREB GOD. 30 (2021), BR. 4, STR. 785-806

BRAUTOVIĆ, M.: CORRECTIONS.. nalism model "that puts the highest value on accuracy and context" has been replaced by a "newer model that puts the highest value on immediacy and volume" (Kovach \& Rosenstiel, 2010, p. 34). The new model in online media has resulted in lower levels of accuracy (Nygren \& Windholm, 2018). The online media thus tend to "prioritise speed on behalf of accuracy" and to "publish their texts in the form of drafts that are under constant alteration" (Nygren \& Windholm, 2018, p. 44). Although speed is not unique to online media (Kovach \& Rosenstiel, 2014), there is evidence that speed is causing inaccuracy through factual/mechanical errors (Berry, 1967; Brautović et al., 2020).

Journalistic accuracy depends greatly on journalism culture, and this study will focus on how journalism culture, as a "set of ideas and practices by which journalists legitimate their role in society and render their work" (Hanitzsch, 2007, p. 369), influences the error correction practice in the Croatian media landscape.

Errors in journalism are not new, but the way in which journalists and editors are handling them is. The problems of journalistic errors and corrective procedures are gradually being researched with an emphasis on news sources, audiences, and their perceptions of errors (Charnley, 1936; Brown, 1965; Berry, 1967; Blankenburg, 1970; Tillinghast, 1982; Urban, 1999; Meyer, 2004; Malović, 1998; Maier, 2007; Cassidy, 2007; Fox et al., 2009; Vilović, 2010; Hebrang, 2010; Smith, 2011; Porlezza et al., 2012; Karlsson et al., 2017). On the other hand, corrections and correction procedures are left aside (Maier, 2007; Silverman, 2007; Smith 2011), although corrections, in all honesty, are the "way the media explain themselves to the public", how they make readers "feel better" about their media (Smith, 2011, p. 83), and increase trust in those media (Kohring \& Matthes, 2007).

\section{DEMOCRACY, INFORMATION QUALITY AND CORRECTIONS}

Accuracy is directly connected to the concepts of objectivity and information (journalism) quality (McQuail, 2010), as the central values of journalism in Western democracies. According to Jeffrey Scheuer (2012), democracy and journalism quality are interconnected, and it is impossible to think about quality in democracy without excellence in journalism. "They are not just accidental neighbours; they are joined at the normative and conceptual hip. There can never be much of one without the other. That is not to say they fit comfortably or neatly, or that everyone will like it" (Scheuer, 2012, p. xii).

Quality in journalism, as a prerequisite for quality in de- 
DRUŠ. ISTRAŽ. ZAGREB GOD. 30 (2021), BR. 4, STR. 785-806

BRAUTOVIĆ, M.: CORRECTIONS.. is gathered, selected, organised, transmitted, and received, influences the ability of people to function as citizens (Scheuer, 2012, p. xi). As Jörgen Westerståhl points out, "...citizens need to be informed of what is happening in the world around them. News reporting must be factual and impartial in order to provide a foundation for independent and rational decision making" (Westerståhl, 1983, p. 407).

If journalists are not able to obtain numbers, names and other facts correctly, they are losing their democratic function. It is not the worst journalistic sin, but it is the one that is the easiest to detect and correct (Scheuer, 2012, p. 66). Hettinga et al. (2018, p. 3) noted that "...because corrections are a critical mechanism for news media's pursuit of accuracy, they are a relevant and significant area of study".

Almost all of the professional journalism codes of ethics regulate accuracy, errors and corrections. The Munich Declaration of the Duties and Rights of Journalists (1971) prescribed that journalists and the media should correct "any published information which has proved to be inaccurate." The Society of Professional Journalists' Code of Ethics states that the journalist should "gather, update and correct information throughout the life of a news story" (Society of Professional Journalists, 2014). Similarly, the Association of Croatian Journalists has regulations that state that a journalist is obliged to correct an error as soon as possible. "The correction should seek to be published in the same, or an equivalent, location in the media space, and in the same, or an equivalent, manner, as the information to which the correction relates" (Association of Croatian Journalists, 2009).

\section{CORRECTIONS, CIRCULATION AND CREDIBILITY}

The professional ethics and democratic function of the media are not the only reason why media should publish corrections. Stephen Lecy and Frederick Fico (1991) found evidence of a strong connection between a newspaper's content, quality and circulation. The newspapers that are lower in quality ended up by losing their audience. Similarly, Philip Meyer (2004, pp. 96-97) proved that circulation robustness depended on the accuracy of the media, with regard to which newspapers with a high level of errors are the least trusted sources. A small-scale study of mathematical inaccuracy in The News $\mathcal{E}$ Observer found a weak, but statistically significant, connection between errors and newspapers' credibility, where the credibility of the media becomes weaker with an increase in the frequency and severity of the errors (Maier, 2003).

Garry Hanson and Stanley T. Wearden (2004) researched the errors at a TV station in Cleveland. They found that subjec- 
DRUŠ. ISTRAŽ. ZAGREB GOD. 30 (2021), BR. 4, STR. 785-806

BRAUTOVIĆ, M.: CORRECTIONS.

vision news, and, in general, than subjective errors in print. This study has proved that errors "have an impact on the perception of journalism", and, because of that, it is "important in the long term for television stations to develop procedures that monitor the factual and subjective accuracy of stories" (Hanson \& Wearden, 2004, p. 546).

"A newspaper that carries corrections does not mean it makes more mistakes than others; it means that it is a good, self-respecting and honest newspaper, which owns up to its errors and corrects them. The best newspapers are bristling with corrections. Bad newspapers hide their mistakes and inflict ignorance, disinformation and propaganda on their readers." (Mathiu, 2019)

\section{CORRECTIONS RATES AND PROCEDURES}

Before the 1970s, the media did not have editorial procedures for handling errors (Silverman, 2007), especially in relation to the procedures for publishing correction notices in order to acknowledge them (Barkin \& Levy, 1983). The situation changed with the introduction of a "new approach to journalistic admissions of error", when the correction started to be "made under a standing headline either on one of the pages near the front or second page of a 'split' section" (Barkin \& Levy, 1983, p. 218). In the last 20 years, as part of self-regulation attempts, many newspapers have introduced a public editor position in an endeavour to overcome "the growing distrust the public has for the news media" (Martin, 2009, p. 1278). Another approach is to have a newspaper ombudsman, who serves as an intermediary between the public and the media, but not as a member of the editorial staff (like the public editor). The ombudsman examines complaints and recommends public corrections, changes in journalism practices, or apologies for errors (Martin, 2009).

In 2007, there were 27 readers' representatives, or ombudsmen, in USA newspapers (Strupp, 2008), but their positions have been virtually eliminated during the last ten years. One of the last public editor positions was at the New York Times, and this position was done away with in 2017, and in such a way that the role was left to readers on the social media (Vore, 2017).

"The public editor position, created in the aftermath of a grave journalistic scandal, played a crucial part in rebuilding our readers' trusts by acting as our in-house watchdog. We welcomed that criticism, even when it stung. But today, our followers on social media and our readers across the internet have come together to collectively serve as a modern watchdog, more vigilant and forceful than one person could ever 
DRUŠ. ISTRAŽ. ZAGREB GOD. 30 (2021), BR. 4, STR. $785-806$

BRAUTOVIĆ, M.: CORRECTIONS.. and to listen to them, rather than to channel their voice through a single office." (Vore, 2017)

Broadcast media have been slower in adopting correction procedures, and their approaches vary. Some broadcast a correction immediately, some correct errors the next time that the show is aired, and some hide their errors (Smith, 2011, p. 85).

Steve M. Barkin and Mark R. Levy (1983) discovered that The New York Times and The Washington Post mainly corrected the objective errors, and that these newspapers had published, on average, one correction per day. Both The New York Times and The Washington Post doubled the number of their corrections in the period 1997-2007 (Nemeth \& Sanders, 2009). Another study showed that, in 2004, The New York Times published an average of nine corrections a day (Martin, 2009).

Ombudsman Gina Lubrano (2006), from The San Diego Union-Tribune, counted 709 errors that were corrected during 2006, and compared that newspaper's results with other similar media. "The Boston Globe tallied more than 1,000 corrections; The Oregonian total dropped to 800; The Orlando Sentinel had 779. Others had fewer, including The Star Tribune in Minneapolis, with 611; The Kansas City Star, with 482, and The Akron Beacon-Journal with 450" (Lubrano, 2006).

The latest study by Hettinga et al. (2018) showed that The New York Times, The Washington Post, The Wall Street Journal and The Los Angeles Times corrected errors similarly to each other in the period 2010-2014. They found that the most common corrected error was located in an article (84\%), and the type of mistake was often incorrect or misspelled names and other personal references $(34.7 \%)$; the errors had a potentially low impact on society $(87.2 \%)$, and newspapers mainly corrected objective errors $(91.3 \%)$. Only a small number of corrected errors were errors of meaning (subjective). This is even more problematic if we know that another study showed that "only $23(2 \%)$ of 300 stories contained errors that resulted in the publication of corrections in the newspapers analysed" (Maier, 2007 , p. 40). When news sources reported the errors to the media, the result was almost the same. "Of 130 news stories in which the news sources said they informed the newspapers of factual inaccuracy, complaints yielded only four published corrections. In other words, the correction rate budged barely higher (three percent compared to two percent) when sources reported factual errors than when they did not inform the newspaper of errors." (Maier, 2009)

Ryan M. Thornburg emphasises that correction procedures in digital media are becoming even more important than in the case of print, because "...an article may gain most of its 
DRUŠ. ISTRAŽ. ZAGREB GOD. 30 (2021), BR. 4, STR. 785-806

BRAUTOVIĆ, M.: CORRECTIONS..

\section{CORRECTIONS IN CROATIAN MEDIA}

visitors days, or even weeks, after it was originally published. Errors in the original article do not end up lining the birdcage or wrapping fish, as do errors in newspaper articles. Instead, they remain linked to blogs; as such, error can get repeated over and over again." (Thornburg, 2011, p. 298)

Brautović et al. (2020) found that of the 107 international online media analysed, only 17 had some way to request an error correction. 74 of the stories analysed had some sort of errors, and two months after the stories were published, 46 stories had not been corrected. A possible explanation for this kind of editorial practice can be found in the reasoning that contemporary media organisations publish multiple versions of a story on different platforms, like the web, mobile phones, social media, etc., so "correcting a simple error becomes an arduous task" (Briggs, 2010, p. 307).

Online media correct the errors in three ways: correcting the article with the error, writing a correction note, and placing it in the article with an error, or creating a webpage with a persistent URL that gathers all correction notes (Thornburg, 2011), which is similar to the Corrections and Clarifications sections in newspapers.

The online environment also gives new opportunities for correcting errors in such a way that it can be much timelier and more useful. "In the age of analog traditional media, the process was flawed by definition, because corrections in newspapers were typically published on Page 2 days or even weeks after the original error... [Online] we can fix the error right in the news article (or video or audio) and append an explanation, thereby limiting the damage, because people new to the article will get the correct information." (Gillmor, 2019)

The journalism profession in Croatia sees errors and corrections as being accidental and unintentional. "Errors are unpleasant, but they happen (mostly) by accident and are not so common... The causes are different: inexperience, inattention, ignorance, unreliable sources, speed; they are often present even when we are not aware of them" (Primorac, 1996, pp. 11-12). That kind of attitude has resulted in inadmissible editorial practices which have placed the problem of correction into the hands of the legal system (Media Act, 2004).

The Media Act (2004) expressly brought with it the legal obligation for the media to publish corrections, and it set formal rules for this. In Article 40, the Media Act (2004) regulated that anyone can request corrections, if the user reasonably requires it, within a 30 days' limit, starting from the day when the news that needs to be corrected was published. Article 41 decreed that the publication of corrections should be "without changes or additions to the same or the equivalent loca- 
DRUŠ. ISTRAŽ. ZAGREB GOD. 30 (2021), BR. 4, STR. $785-806$

BRAUTOVIĆ, M.: CORRECTIÓNS. tion of the program space" (Media Act, 2004). Article 41 also specified that "a correction shall not be published without the consent of the user in sections like 'responses' or 'letters from readers, or viewers or listeners"' (Media Act, 2004). In 2013, amendments to the Media Act (2004) "introduced the crime of shaming, a variant of defamation that can be invoked by the injured person if they feel shamed by an article, even if the article says the truth. It is up to the judge, then, to assess whether there was a public interest in publishing the fact" (Vale, 2019). As a result of the Media Act (2004), to be able to sue the media and journalists, the 'injured person' first needs to request a correction. Only in a case where the correction was not published, or where it was published, but not in the way that the Media Act (2004) regulates, or when it does not satisfy the 'injured person', can the case be taken to trial before a court.

The practice of the non-correction of errors has been reflected in an increase in the number of lawsuits against the Croatian media and journalists. The Association of Croatian Journalists (HND) reported that there had been 1,163 court cases against journalists and the media by February 2019. The largest numbers of lawsuits were filed against Hanza Media (459), Styria (420), Slobodna Dalmacija (100), index.hr (71), Nacional.hr (22), telegram.hr (21), etc. (Wiesner, 2019). While professional associations, such as the Association of Croatian Journalists and the European Federation of Journalists, claim that "...such illogical verdicts ...could be interpreted as attacks against freedom of expression" (Vale, 2019), it is clear that editorial practices generated legal pursuit in which the problems of errors and corrections were regulated in the Media Act (2004), with its upgrades (2013), which are increasingly rigid for the journalism profession.

According to journalism professor Gordana Vilović, "most of the Croatian daily newspapers' newsrooms did not have a positive attitude towards publishing corrections" (2010, p. 76) and "the editors obviously do not believe in the thesis that regularly published corrections were increasing the level of newspaper credibility" (2010, p. 75). Vilović analysed Croatian daily newspapers (Večernji list, Jutarnji list, Vjesnik and $24 s a t a)$, and their routines in relation to publishing corrections. Of the 4 daily newspapers analysed, only Večernji list had a section in which they were publishing corrections beyond the reader's requests (Vilović, 2010, p. 75).

Večernji list published an average of two corrections per day, Jutarnji list published corrections only when the aggrieved parties referred to the Media Act (2004), while the other media analysed did not have any corrections (Vilović, 2010, pp. 75-76). Večernji list introduced an ombudsman in March 2008 (Bender, 2008), and some of the corrections were not initiated by the legal obligation to post a correction and/or by readers. In some 
DRUŠ. ISTRAŽ. ZAGREB GOD. 30 (2021), BR. 4, STR. 785-806

BRAUTOVIĆ, M.: CORRECTIONS..
TABLE 1

Number of corrections published in Croatian media cases, corrections contained an appropriate apology and the admission of errors. Unfortunately, the ombudsman position was eliminated when the only ombudsman in the Croatian media, and in Večernji list's history, Ružica Cigler, retired (Galić, 2018). This was not surprising, because ombudsmen positions were first targeted for cuts in the USA, through a similar procedure: not replacing the outgoing ones (Strupp, 2008).

Vladimira Hebrang (2010, p. 61) "found that publishers of leading Croatian newspapers, with predominantly political content, avoid publishing a correction, indicating that there is a high degree of deviation in the application of legal rules that should protect legal entities from semantically harmful information. Editors-in-chief give preference to post-hybrid or covert updates outside of the social box media responsibilities." Hebrang found that, in the first six months of 2009, the analysed political newspapers and magazines (Večernji list, Jutarnji list, Nacional and Globus) did not publish any corrections under such a name. Instead, corrections were published under names like 'letters to the editors' (pisma uredništvu), 'corrections and clarifications' (ispravci i objašnjenja), 'responses' (reagiranja), and 'letters from readers' (pisma čitatelja), in such a way that it did not take into account the ordering and the placement of publication (Hebrang, 2010, pp. 55-56). In 180 days, two daily newspapers and two magazines published a total of 72 corrections, of which $30 \%$ were labelled as responses, and $25 \%$ as corrections and clarifications (Hebrang, 2010, p. 57).

\begin{tabular}{lcc}
\hline Medium / section & $\begin{array}{c}\text { Number of corrections } \\
\text { (January 1 - June 30, 2009) } \\
\text { (Hebrang, 2010) }\end{array}$ & $\begin{array}{c}\text { Number of corrections } \\
\text { (May 6 - May 31, 2010) } \\
\text { (Vilović, 2010) }\end{array}$ \\
\hline Jutarnji list & 34 & 24 \\
Večernji list & 25 & 78 \\
24sata & - & 0 \\
Vjesnik & - & 1 \\
Globus & 6 & - \\
Nacional & 7 & - \\
\hline
\end{tabular}

Source: Hebrang, 2010, p. 56; Vilović, 2010, pp. 73-75.

\section{RESEARCH QUESTIONS}

- The purpose of this study is to investigate what the errors that are corrected in the Croatian online media are, and how these corrections differ. Instead of setting a hypothesis, we asked some research questions:

RQ1: How are errors corrected in Croatian online media?

RQ2: Are there any differences in the corrections in different types of online media? 
(1) TABLE 2

Explanation of the

"type of error" category
For this study, the content analysis codebook was adopted from Martin and Martin's (2018) and Appelman and Hettinga's (2015) work, which was based on previous classification schemes that were developed by Charnley (1936) and Tillinghast (1982). Their codebook was adjusted to be specific to the online media and the Croatian media landscape. The content analysis had these categories: the name of the medium, the type of medium, the date of the published correction, the type of error, the label of the correction, the location of the error, the location of the correction, who requested the correction, linking practice, the presence of an apology, the correction of the incorrect article, and the use of other media as the source of an error in the incorrect article.

The "type of media" had two subcategories: traditional media (1) and online media (2). The Type of error category had the subcategories: spelling/typographical error (1), error of quantification (2), time/date (3), incorrect reporting of proper noun (4), incorrect historical reference (5), error of action (6), attributing a statement to the wrong source (7), incorrect description/interpretation of law or public policy (8), visual/graphical error (9), incorrect geographical reference (10), scientific misinterpretation (11), and other (12) (Martin \& Martins, 2018, p. 255).
Category

(Martin \& Martins, 2018)

Spelling/typographical error

Error of quantification

Time/date

Incorrect reporting of proper noun

Incorrect historical reference
Examples

Names of people and organisations spelled incorrectly

Misreporting of numbers; For example, on October 7, 2008, jutarnji.hr published a correction entitled "Correction: Intesa dropped 29,8\%", in which Jutarnji's newsroom apologised, and corrected the percentage of the drop in the Intesa bank's stocks. In the original story, jutarnji.hr reported that the drop was $68.7 \%$, but the correct number was $29.8 \%$.

https://www.jutarnji.hr/naslovnica/ispravak-intesa-pala-293-3903459

Wrong time or date

Misidentification of people or institutions; For example, on January 17, 2017, vecernji.hr corrected the story published on the previous day, which was entitled "A Turkish Airlines cargo plane crashed in Kyrgyzstan, killing at least 37 people". The journalist wrongly assigned the crash to Turkish Airlines, although it was another Turkish company, ACT Airlines, that oper ated the plane.

https://www.vecernji.hr/vijesti/reagiranje-turkish-airlinesa-na-vijestobjavljenju-na-portalu-vecernjihr-1142885

Misreporting historical facts that can be easily fact-checked; For example, on June 18, 2009, jutarnji.hr published the correction for the story "The artillery logs were taken by Gotovina, and some of them were burned". The journalist was quoting a non-existent part of the Ministry of Justice's report so as to confirm his views on the events during and after the wars in the 1990s. https://www.jutarnji.hr/naslovnica/jurica-sare-nije-pomogao-gotovini2816630 
Misclassification of the situation, or ignoring all the relevant facts as result of bias or slip; For example, after a series of articles published in vecernji.hr in January, 2008, the newsroom apologised and corrected the rumour that the security guard had organised his own kidnapping and robbery. The reports were written based on unverified information coming from a source in the local police which presented "all possible scenarios" of the robbery. https://www.vecernji.hr/vijesti/zastitar-goran-safic-nije-sudionik-otmice838692

Attributing a statement to the wrong source

Incorrect description/interpretation of law or public policy

Visual/graphical error

Incorrect geographical reference

Scientific misinterpretation
Misidentification of the source quoted; For example, on January 10, 2017, vecernji.hr published a correction in which the Institute Ruđer Bošković claimed that they were not the authors of the environmental impact study that was mentioned in the story "One billion euros in the heart of Zagora", which was published on December 29, 2016.

https://www.jutarnji.hr/vijesti/hrvatska/ispravak-netocnih-navoda-oinstitutu-ruder-boskovic-5489531

Misreporting about laws or policies. For example, in the story published on May 10, 2011, vecernji.hr announced the new Croatian housing loan subsidy program and wrongly reported that the users were obliged to return the subsidy at the end of the loan period. The next day, vecernji.hr published an apology and corrected the information.

https://www.vecernji.hr/vijesti/drzavi-se-po-isteku-stambenog-kredita-nevraca-nista-285988

Misidentifications of people in a photo, or wrong data in tables/graphics; For example, tportal.hr on October 20, 2009, published the story "The adul terous nest is owned by Kerum's wife", with a photo of the wrong woman as an illustration of the mistress of the mayor of the city of Split. Several days afterwards, tportal.hr apologised and erased the photo. https://www.tportal.hr/vijesti/clanak/ispravak-teksta-preljubnickognijezdo-u-vlasnistvu-je-kerumove-supruge-20091105/print

Wrong location or address

Incorrectly reporting scientific and mathematical facts that can be easily fact-checked.

Based on the practices in the Croatian traditional media, we formed the category "label of the correction", which had the subcategories: letters to the editors (pismo uredništvu) (1), correction (ispravak) (2), response (reagiranje) (3), and letters from readers (pismo čitatelja) (4). This category was used to determine the editorial attitudes regarding the corrections.

The category "location of the correction" had these subcategories: corrected article (1), correction note next to the article (2), correction note on the subpage that gathers all correction notes (3), independent note with reference to the print article (4), independent note without a link to the article (5), independent note with link to the article (6), and other (7). This category (location of the correction) was developed based on the work of Thornburg (2011), but was updated to be specific to the Croatian media landscape.

To further explain the practices, the categories "linking practice", "presence of the apology", "correction of the incorrect 
(1) TABLE 3 Explanation of the "linking practice" category

article", and "use of other media as source of error in incorrect article" were added. "Linking practice" had the subcategories: link to the article (1), link to the article and backlink to the correction note (2), link to the erased article (3), no link (4).

Link to the article

Link to the article and

backlink to the correction note

Link to the erased article
Correction note linked to erroneous article; For example, on February 24 2016, vecernji.hr published a correction note entitled "Marta Žegura denies Frane Perišin's statements: She reported him for harassment and intimidation", which was linked to the original article. The original article was not linked to the correction note, and that left the possibility that someone could find the original article through, e.g., Google search, and not read the correction.

https://www.vecernji.hr/showiz/marta-zegura-negira-izjave-frane-perisina1062870

Correction note linked to an erroneous article, and erroneous article linked to correction note; For example, on July 20, 2011, vecernji.hr published a story entitled "A customs officer in Plovanija asked a Slovak woman to satisfy him orally?" This was written based on one accusation made by people who were involved in the incident. The next day, the correction was published, which came from an official source that corrected the original article. The original article and correction note were interlinked.

https://www.vecernji.hr/vijesti/carinska-uprava-sluzbenici-nisu-umijesaniu-incident-na-plovaniji-312213

Correction note linked to an erroneous article, which was, after the discovery of the error, erased; For example, on October 8th, 2014, jutarnji.hr published an article "The state offers Croatia Airlines again: Will anyone be interested in the stumbling company?", which was corrected 16 days later. Although the correction note contained a link to the original article, the article was erased, and the link was broken.

https://www.jutarnji.hr/incoming/croatia-airlines-nije-posrnula-tvrtkasvi-gubici-su-pokriveni/569416/

No link
Correction note without a link to the erroneous article; For example, on August 26th, 2011, jutarnji.hr published an article "Mrčela suspected of 4.8 million". The article was corrected on September 22nd, 2014, but without a link that leads to the original article.

https://www.jutarnji.hr/vijesti/hrvatska/mrcela-osumnjicen-za-48milijuna-kuna-ispravak-netocnog-navoda/1821051/

The category "presence of apology" had the subcategories: the existence of an apology (1), and the absence of an apology (2). The category "correction of the incorrect article" had the subcategories: corrected (1), non-corrected (2), erased article (3), and other (4).

"Use of other media as the source of error in the incorrect article" was used to determine whether the report used other media reports as a source in the article that contained the errors. This category had two subcategories: media as source of error (1), and other (2).

"Location of the error" had the subcategories: article (1), headline (2), photo (3), video (4), cutline (5), byline/credit (6), infographic (7), link (8), and other (9) (Appelman \& Hettinga, 
DRUŠ. ISTRAŽ. ZAGREB GOD. 30 (2021), BR. 4, STR. 785-806

BRAUTOVIĆ, M.: CORRECTIONS..

\section{Sample}

(1) TABLE 4 Selection of media for analysis

2015, pp. 5-6). The category "who requested the correction?" had the subcategories: regular person (1), journalist/ editor (2), legal official (3), government official (4), politician (5), private organisation/company (6), and other (7).

The study investigated corrections that had been published in the online editions of three newspapers, and in three of the online media, in the last 10 years. Similarly to Appelman and Hettinga (2015), the selection of the media for analysis was made based on the criteria of circulation and quality. Additional selection criteria were whether the medium was part of the journalistic corrections' research. For analysis of traditional media that had online counterparts, Večernji list (vecernji.hr), Jutarnji list (jutarnji.hr) and 24sata (24sata.hr) were selected, and for the analysis of online media only, selected were index.hr, net.hr and tportal.hr.

In Croatia, there were no commercial news databases that the researcher could use for the analysis of media content, as Hettinga et al. (2018) had. Instead, the sample was extracted from the Google Search results, following the use of the keywords "ispravak site:URL" (without quotation marks; URL of media analysed. The search was limited to the period from January 1, 2008, to December 31, 2018. It should be emphasised that an internal website search could not be used, because some of the media analysed used Google search for their internal search engine (net.hr), or the list of results after an internal search resulted in a smaller number of potential corrections than a Google search did (for example, a tportal.hr internal search had 116 results, compared to a Google search, which had 177).

\begin{tabular}{llcc}
\hline Medium & Type of media & $\begin{array}{c}\text { Rank according to } \\
\text { Alexa.com (2019) }\end{array}$ & $\begin{array}{c}\text { Rank according to } \\
\text { Gemius (2019) }\end{array}$ \\
\hline 24sata.hr & Traditional/Newspapers & 5 & 1 \\
dnevnik.hr* & Traditional/Broadcast & 16 & 2 \\
vecernji.hr & Traditional/Newspapers & 19 & 3 \\
rtl.hr* & Traditional/Broadcast & 18 & 4 \\
tportal.hr & Online & 20 & 5 \\
net.hr & Online & 12 & 6 \\
telegram.hr* & Online & 38 & 8 \\
poslovni.hr* & Traditional/Newspapers & - & 9 \\
dnevno.hr* & Online & - & 10 \\
jutarnji.hr & Traditional/Newspapers & 7 & - \\
index.hr & Online & 6 & - \\
\hline
\end{tabular}

${ }^{*}$ Media not selected for analysis. 
DRUŠ. ISTRAŽ. ZAGREB GOD. 30 (2021), BR. 4, STR. 785-806

BRAUTOVIĆ, M.: CORRECTIONS.

\section{RESULTS}

The Google search produced a list of 1,462 results, which was reduced to 320 actual corrections $(N=320)$, when duplicates, user comments, pages and tag lists, broken links, correction outside the period January 1, 2008 - December 31, 2018 , and other non-related content were excluded. The sample included 32 corrections from vecernji.hr $(N=32), 120$ from jutarnji.hr $(N=120), 13$ from 24sata.hr $(N=13), 56$ from index.hr $(N=56), 68$ from tportal.hr $(N=68)$, and 31 from net.hr $(N=31)$, or 165 from traditional media $(N=165)$ and 155 from online only media $(N=155)$.

The collection was scraped using the Data Miner extension of Google Chrome. The units of analysis were corrections that acknowledged at least one factual error, and that were labelled as corrections (ispravak), letters to the editors (pisma uredništvu), corrections and clarifications (ispravci i objašnjenja), responses (reagiranja), and letters from readers (pisma čitatelja).

\section{RQ1: Practice of correcting errors in Croatian online media}

Out of 320 corrections examined $(N=320), 73.4 \%(N=235)$ were labelled as "corrections", $14.6 \%(N=47)$ were labelled as "responses", and 11.5\% ( $N=27)$ belonged in the category "other", which included labels like "request for correction".

An error of action or meaning $(N=217)$ represented $67.8 \%$ of all errors. Furthermore, the incorrect description of law/ public policy errors made up $13.1 \%(N=42)$, and statements giving the wrong source amounted to $8.4 \%(N=27)$ of all of the errors analysed. At the same time, errors such as incorrect historical references, statements attributed to the wrong person, errors of quantification, incorrect reporting of a proper noun, incorrect quotation, and visual/graphical error, amounted to only $8.75 \%(N=34)$ of the total sample. Based on the sample analysed, typographical/spelling errors, wrong times/dates, incorrect geographical references and scientific misinterpretations, were neither corrected nor present.

The most common way of correcting errors in the Croatian online media was by posting an independent note (post) about an error that was linked to the incorrect article $(59 \%, N=$ 188). The second, and the most common practice, was posting an independent note without a link to the incorrect article ( $40 \%, N=128$ ). The error-correcting practices, like writing the correction note and placing it on the article that contained an error, or creating a webpage with a permanent URL that gathers all of the correction notes, were, in practice, missing. Only 
DRUŠ. ISTRAŽ. ZAGREB GOD. 30 (2021), BR. 4, STR. 785-806

BRAUTOVIĆ, M.: CORRECTIONS.. three corrections were made in relation to the way in which the article was corrected and then had the correction note next to it. None of the six media analysed had a dedicated webpage on which the audience could access the previous corrections.

The practice of using independent correction notes that had links to the articles varied in three ways: note linked to deleted article $(6.9 \%, N=13)$, note linked to the article $(60.1 \%$, $N=113$ ), and note linked to article with backlink to correction note $(32.9 \%, N=62)$. The correction notes were linked to the uncorrected articles in $85.1 \%(N=159)$ cases, and to corrected articles in $8.5 \%(N=16)$ of the cases analysed. In only a small number of the corrections analysed $(8.4 \%, N=27)$ were journalists apologising for errors.

Errors were located mainly in the articles $(93.7 \%, N=300)$, and occasionally in photos $(3.7 \%, N=12)$ and headlines $(0.9 \%$, $N=3)$. In $7.8 \%$ of the cases $(N=27)$, the online media were correcting articles that were using other media as sources.

Lawyers $(37,8 \%, N=121)$ most often demanded the correction of the errors. They were followed by government officials $(17.1 \%, N=55)$, regular people $(15.3 \%, N=49)$, and private organisations $(12.5 \%, N=40)$. The smallest number of those requesting corrections were journalists $(6.2 \%, N=20)$, legal officials $(4 \%, N=13)$, and politicians $(1.2 \%, N=4)$.

\section{RQ2: Differences in the correction practices of online only and the online outlets of traditional media}

A chi-square test of independence was calculated to determine the differences between the type of media and the correction practices. Analysis showed no significant difference between the type of error and the online only media and online outlets of the traditional media, $\chi^{2}(8, N=320)=9.09, p>0.05$. The correction procedures also did not differ through the correction of the incorrect article, $\chi^{2}(4, N=188)=0.4, p>0.05$, and the use of other media as the source of the error in the incorrect article, $\chi^{2}(2, N=188)=1.5, p>0.05$.

Analysis showed a significant difference between the labelling of the correction and the type of media, $\chi^{2}(3, N=320)=$ $15.7, p<0.001$. Online outlets of traditional media were more likely to label corrections as "requests for correction", while online only media were more likely to label corrections as "responses".

Similarly, there was a significant relationship between the type of media and the location of the correction, $\chi^{2}(4, N=$ $320)=13.4, p<0.01$. The online outlets of the traditional media were more likely to post corrections without linking them to the incorrect article, while online only media were more likely to link corrections to articles that were related to them. 
DRUŠ. ISTRAŽ. ZAGREB GOD. 30 (2021), BR. 4, STR. 785-806

BRAUTOVIĆ, M. CORRECTIONS.

$\vartheta$ FIGURE 1 label of the correction and type of media
Difference between

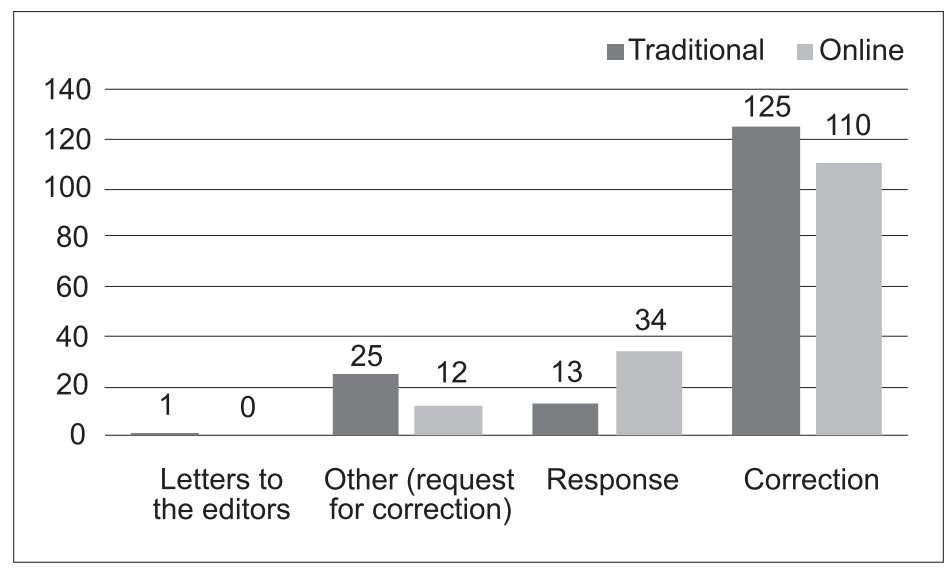

$\rightarrow$ FIGURE 2

Difference between the type of media and the location of the correction

(1) FIGURE 3

Difference between who is requesting correction and the type of media

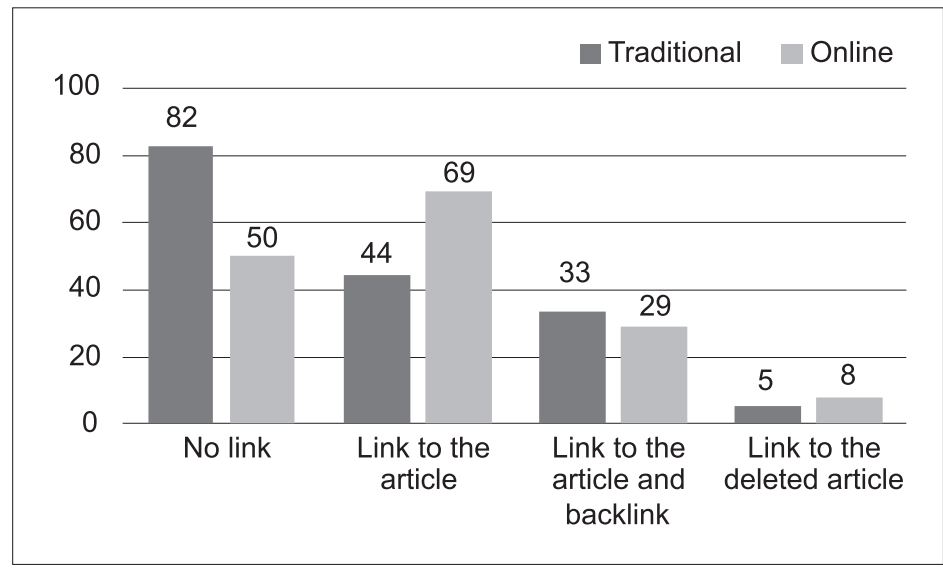

Traditional Online

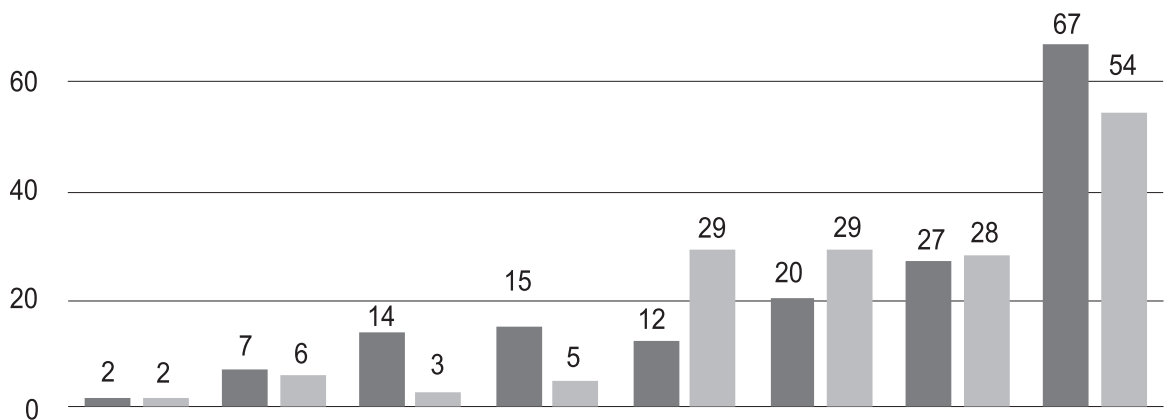

0

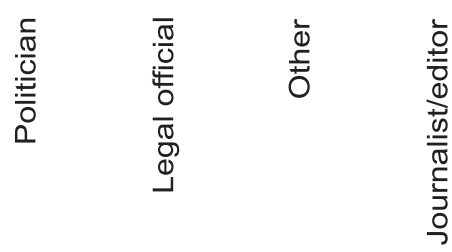

\begin{tabular}{|c|}
\hline 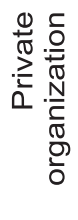 \\
\hline
\end{tabular}


DRUŠ. ISTRAŽ. ZAGREB GOD. 30 (2021), BR. 4, STR. 785-806

BRAUTOVIĆ, M.: CORRECTIONS.
The chi-square test of independence showed that there was a significant association between who was requesting the correction and the type of media, $\chi^{2}(7, N=320)=22.1, p<0.01$. Lawyers and journalists were more likely to request corrections in the online counterparts of the traditional media than in online only media. At the same time, regular people and private organisations were more likely to request corrections in online only media, if compared to the online outlets of the traditional media.

\section{DISCUSSIONS \& CONCLUSIONS}

The practice of correcting errors in Croatian online media varies from the Westernised practice in several ways. The first difference that was found was the difference in the frequency of corrections. On average, Croatian online media have only a few corrections a year, and an average American and European medium publishes at least a few a day. The majority of the corrected errors in American newspapers were trivial (Hettinga et al., 2018), while the majority of the corrections in the Croatian online media were subjective, with the dominance of errors of action and the incorrect description/interpretation of the law or of public policy. Croatian online media were not serving their watchdog function better than the media in the West were, because an explanation could be found in the practice coming from the Media Act and the avoidance of responsibility for libel. The findings showed that lawyers and government officials $(54.9 \%)$ most often requested corrections as the first step in legal proceedings against journalists/media and, on the other hand, the media published these corrections to avoid lawsuits.

The journalism practices also varied in the way that Croatian journalists labelled corrections. While many corrections were labelled as corrections, many were named "responses", or "requests for correction". This practice was taken from Croatian print journalism culture (Hebrang, 2010). Similarly, Croatian journalists and editors rarely apologised for errors. One rare example of an apology was published by $\mathrm{Ve}$ černji list when they published the photo of a person who was not involved in the crime story, as an illustration. Večernji list's newsroom wrote "The fraud mentioned in the article is in no way related to Ms Rebrača or her salon. We apologise to Ms Rebrača for the inconvenience she experienced as a result of our publishing the photo" (Večernji list, 2011).

Further, the Croatian online media invented their own correction formats in the form of the independent note, but they left the uncorrected article online in $85.1 \%$ of the cases. 
DRUŠ. ISTRAŽ. ZAGREB GOD. 30 (2021), BR. 4, STR. $785-806$

BRAUTOVIĆ, M.: CORRECTIÓNS. found in the need to formally satisfy the Media Act (2004), but not to make the media accountable and credible. For example, a journalist, Anita Malenica (2011a), wrote a story in which she mentioned that a leading political party (the Croatian Democratic Union) politician, Andrija Hebrang, had left the party and later returned, a statement which was confirmed as being false within hours. Malenica issued the apology in an independent note, without linking it with the original story (and vice versa) or correcting the original story (Malenica, 2011b).

Such practices also create problems for the media themselves. If articles and correction notes are not mutually linked, there is a considerable chance that a person who searches for that kind of information will not find both, and will therefore probably use the wrong information. As online media are increasingly using other media as sources in their reporting (Brautović et al., 2020), this kind of practice also creates problems for them. The findings show that $7.8 \%$ of the corrections analysed corrected errors in articles that were using other media as their sources. In one recorded case, tportal.hr corrected an article that was based on an incorrect article on Energetika.net, which had previously been corrected by an independent note.

Linking practices, the error correction of original articles and the scanning of the corrections, can be considered to be strategies that are used by the Croatian online media to bypass the legal responsibility for libel. An example is index.hr, which has the practice of publishing a scanned version of corrections $(N=19)$ that cannot be indexed by search engines, and the audience will thus have problems finding them, which, additionally, offers proof of the previous reasoning.

If we exclude the category that refers to who it is that is requesting corrections, because it does not present the practice of the newsroom, but is a reaction to their practices, the only statistically significant difference between the traditional and the online only media was in their labelling practice and the location of the correction. The first category shows a different format to print media correction practice, and the second category shows that online only media were more adapted to the internet environment, in which linking is the essence of the medium. The absence of linking and/or no-interlinking shows the level of the media's commitment to correcting errors.

Although the sample analysed does not represent all of the corrections in the Croatian online media, it does describe the journalism culture that dominates in the Croatian (online) media landscape. The findings, which are in line with previous research on Croatian newspapers (Vilović, 2010; Hebrang, 2010), 
DRUŠ. ISTRAŽ. ZAGREB GOD. 30 (2021), BR. 4, STR. 785-806

BRAUTOVIĆ, M.: CORRECTIONS. prove that "...old values are transferred into new media platforms, and formats and differences between journalistic cultures remain..." (Nygren \& Widholm, 2018, p. 56). They also question previous studies that have perceived the online media to be less trustworthy than their traditional equivalents (Grosser et al., 2016).

\section{Limitations and further research}

The study was limited by the selection of the sample. Namely, based on the data collected it was impossible to determine how correction notes were displayed on the home pages, or the subpages, when they were originally published. Furthermore, as there has been no previous research on corrections in online journalism, the codebook was adopted from one for newspapers, and was adjusted to fit Croatian journalism practices. Additionally, the study did not analyse unlinked and deleted articles, which might provide more insights into correction practices in the Croatian media landscape.

The findings of the study need to be further clarified through observation in newsrooms, and by in-depth interviews with journalists and the editors of online media.

\section{REFERENCES}

Alexa.com. (2019). Top sites in Croatia. Alexa. https://www.alexa.com/ topsites/countries/HR

Appelman, A., \& Hettinga, K. E. (2015). Error message: Creation and validation of a revised codebook for analysis of newspaper corrections. AEJMC. Paper presented at AEJMC 2015 San Francisco, CA.

Association of Croatian Journalists (2009). Kodeks časti hrvatskih novinara [Croatian Journalists' Association's Code of Honor]. Association of Croatian Journalists. https://www.hnd.hr/kodeks-casti-hrvatskih-novinara

Barkin, S. M., \& Levy, M. R. (1983). All the news that's fit to correct: Corrections in the 'Times' and the 'Post'. Journalism and Mass Communication Quarterly, 60(2), 218-225. https://doi.org/10.1177/10776990 8306000202

Bender, S. (2008, March 26). Zastupnica čitatelja - dijalog između novinara i čitatelja [Reader's ombudsman - a dialogue between a journalist and a reader]. Večernji list. https://www.vecernji.hr/vijesti/zastup nica-citatelja-dijalog-izmedju-novinara-i-citatelja-839699

Berry, F. (1967). A study of accuracy in local news stories of three dailies. Journalism Quarterly, 44(3), 482-490. https://doi.org/10.1177/10 7769906704400309

Blankenburg, W. B. (1970). News accuracy: Some findings on the meaning of errors. Journal of Communication, 20(4), 375-386. https://doi.org/ 10.1111/j.1460-2466.1970.tb00896.x

Brautović, M., Buratović Maštrapa, S., \& John, R. (2020). Accuracy in online media: Insufficient journalistic routines in fact-checking and corrections. Medijske studije, 11(21), 66-86. https://doi.org/10.20901/ms. 11.21.4 
DRUŠ. ISTRAŽ. ZAGREB GOD. 30 (2021), BR. 4, STR. 785-806

BRAUTOVIĆ, M.: CORRECTIÓNS..
Briggs, M. (2010). Journalism Next. CQPress.

Brown, C. H. (1965, February 13). The majority of readers give papers an A for accuracy. Editor $\mathcal{E}$ Publisher, 63.

Cassidy, W. P. (2007). Online news credibility: An examination of the perceptions of newspaper journalists. Journal of Computer-Mediated Communication, 12(2), 478-498. https://doi.org/10.1111/j.1083-6101.2007. 00334.x

Charnley, M. (1936). Preliminary notes on a study of newspaper accuracy. Journalism \& Mass Communication Quarterly, 13(4), 394-401. https://doi.org/10.1177/107769903601300403

Fox, C., Knowlton, S., Maguire, Á., \& Trench, B. (2009). Accuracy in Irish newspapers. Press Council of Ireland. http://www.presscouncil.ie/_file upload/Accuracy\% 20research\%20report\% 200609\%20(Final).pdf

Galić, M. (2018). Tranzicija dnevnih tiskovina u e-publikacije [Transition of traditional publications to e-publications]. (Doctoral dissertation). University of Zagreb. http://darhiv.ffzg.unizg.hr/id/eprint/10907/1/ Galic_Marin.pdf

Gemius (2019). Domains. https://rating.gemius.com/hr/tree/8

Gillmor, D. (2019). Can our corrections catch up to our mistakes as they spread across social media? NiemanLab. https://www.niemanlab.org/ 2019/03/can-our-corrections-catch-up-to-our-mistakes-as-they-spreadacross-social-media/

Grosser, K. M., Hase, V., \& Blöbaum, B. (2016). Trust in online journalism. In B. Blöbaum (Ed.), Trust and communication in a digitized world (pp. 53-73). Springer. https://doi.org/10.1007/978-3-319-28059-2_3

Hanitzsch, T. (2007). Deconstructing journalism culture: Toward a universal theory. Communication Theory, 17(4), 367-385. https://doi.org/ 10.1111/j.1468-2885.2007.00303.x

Hanson, G., \& Wearden, S. T. (2004). Measuring newscast accuracy: Applying a newspaper model to television. Journalism \& Mass Communication Quarterly, 81(3), 546-558. https://doi.org/10.1177/10776990 0408100306

Hebrang, V. (2010). Ostvarivanje prava na ispravak medijske objave [The right of correction of the media announcement]. Medianali, 4(8), 43-63.

Hettinga, K., Appelman, A., Otmar, C., Posada, A., \& Thompson, A. (2018). Comparing and contrasting corrected errors at four newspapers. Newspaper Research Journal, 39(2), 155-168. https://doi.org/10.11 77/0739532918775685

Karlsson, M., Clerwall, C., \& Nord, L. (2017). Do not stand corrected: Transparency and users' attitudes to inaccurate news and corrections in online journalism. Journalism \& Mass Communication Quarterly, 94(1), 148-167. https://doi.org/10.1177/1077699016654680

Kohring, M., \& Matthes, J. (2007). Trust in news media: Development and validation of a multidimensional scale. Communication Research, 34(2), 231-252. https://doi.org/10.1177/0093650206298071

Kovach, B., \& Rosenstiel, T. (2010). Blur: How to know what's true in the age of information overload. Bloomsbury. 
DRUŠ. ISTRAŽ. ZAGREB GOD. 30 (2021), BR. 4, STR. 785-806

BRAUTOVIĆ, M.: CORRECTIONS..
Kovach, B., \& Rosenstiel, T. (2014). The elements of journalism. 3rd ed. Three Rivers Press.

Lecy, S., \& Fico, F. (1991). The link between newspaper content quality \& circulation. Newspaper Research Journal, 12(2), 46-57. https://doi. org/10.1177/073953299101200206

Lubrano, G. (February 6, 2006). Errors and a newspaper's credibility. The San Diego Union-Tribune. https://advance.lexis.com/api/document? collection = news\&id = urn:contentItem:4J73-6R40-TWDC-M2JP-0000000\&context $=1516831$

Maier, S. R. (2003). How sources, reporters view math errors in news. Newspaper Research Journal, 24(4), 49-63. https://doi.org/10.1177/07395 3290302400405

Maier, S. R. (2007). Setting the record straight: When the press errs, do corrections follow? Journalism Practice, 1(1), 33-43. https://doi. org/10.1080/17512780601078845

Maier, S. R. (2009). Confessing errors in a digital age. Nieman Reports. https://niemanreports.org/articles/confessing-errors-in-a-digital-age/

Malenica, A. (2011a, June 6). J. Kosor na susretu s papom s novom okosnicom HDZ-a [J. Kosor at a meeting with the Pope on the new backbone of the HDZ]. Večernji list. https://www.vecernji.hr/vijesti/jkosor-na-susretu-s-papom-s-novom-okosnicom-hdz-a-296825

Malenica, A. (2011b, June 6). Andrija Hebrang nikad nije prestao biti član HDZ-a [Andrija Hebrang never stopped being a member of the HDZ]. Večernji list. https://www.vecernji.hr/vijesti/andrija-hebrangnikad-nije-prestao-biti-clan-hdz-a-297347

Malović, S. (1998). Pogreške u tisku: plod nemara, neznanja ili namjere? [Printing errors: A consequence of negligence, ignorance, or design?]. Politička misao, 35(1), 186-198.

Martin, J. D., \& Martins, R. J. (2018). Outsourced credibility? Journalism Studies, 19(2), 247-267. https://doi.org/10.1080/1461670X.2016.1178594 Martin, R. A. (2009). Self-regulation. In The Encyclopedia of Journalism. Sage Publications. https://doi.org/10.4135/9781412972048.n349

Mathiu, M. (February 8, 2019). It is by correcting errors that we end up with quality product. Daily Nation (Kenya). https://advance.lexis.com/ api/document?collection $=$ news\&id = urn:contentItem:5VCG-XVD1F11P-X1WC-00000-00\&context $=1516831$

McQuail, D. (2010). McQuail's mass communication theory (6th ed.). Sage. Media Act (2004). Official Gazette, No 59/04, 84/11, 81/13. https://www. zakon.hr/z/38/Zakon-o-medijima

Meyer, P. (2004). The vanishing newspapers: Saving journalism in the information age. University of Missouri Press.

Munich Declaration of the Duties and Rights of Journalists (1971). http://www. mediawise.org.uk/european-union/

Nemeth, N., \& Sanders, C. (2009). Number of corrections increase at two national newspapers. Newspaper Research Journal, 30(3), 90-104. https://doi.org/10.1177/073953290903000307

Nygren, G., \& Widholm, A. (2018). Changing norms concerning verification: Towards a relative truth in online news? In K. Otto \& Köhler 
DRUŠ. ISTRAŽ. ZAGREB GOD. 30 (2021), BR. 4, STR. 785-806

BRAUTOVIĆ, M.: CORRECTIONS..
A. (Eds.), Trust in media and journalism: Empirical perspectives on ethics, norms, impacts and populism in Europe (pp. 39-59). Springer VS. https:// doi.org/10.1007/978-3-658-20765-6_3

Primorac, S. (1996). Tipične pogreške u pisanju vijesti [Typical mistakes in writing news]. In S. Ricchiardi \& S. Malović (Eds.), Uvod $u$ novinarstvo [Introduction to journalism] (pp. 11-19). Izvori.

Porlezza, C., Maier, S. R., \& Russ-Mohl, S. (2012). News accuracy in Switzerland and Italy: A transatlantic comparison with the US press. Journalism Practice, 6(4), 530-546. https://doi.org/10.1080/17512786. 2011.650923

Scheuer, J. (2012). The big picture: Why democracies need journalistic excellence. Routledge. https://doi.org/10.4324/9780203939437

Silverman, C. (2007). Regret the error: How media mistakes pollute the press and imperil free speech. Union Square Press.

Society of Professional Journalists. (2014). SPJ Code of ethics. Society of Professional Journalists. https://www.spj.org/ethicscode.asp

Smith, R. (2011). Ethics in journalism. Wiley.

Strupp, J. (2008, September 1). These ombuds no longer for you. Editor \& Publisher. https://www.editorandpublisher.com/news/these-ombudsno-longer-for-you

Thornburg, R. M. (2011). Producing online news: Digital skills, stronger stories. CQPress.

Tillinghast, W. A. (1982). Newspaper errors: Reporters dispute most source claims. Newspaper Research Journal, 3(4), 14-23. https://doi.org/10. 1177/073953298200300403

Urban, C. (1999). Examining our credibility: Perspectives of the public and the press. News Leaders Association. http://files.asne.org/kiosk/reports/ 99reports/1999examiningourcredibility/Index.html

Vale, G. (2019, February 7). Croatia, a thousand lawsuits against journalists. SEENPM. https://seenpm.org/croatia-thousand-lawsuits-journalists/

Večernji list (2011, April 27). Vlasnica kozmetičkog salona nema veze $\mathrm{s}$ bandom pljačkaša [The owner of the beauty salon has nothing to do with the gang of robbers]. Večernji list. https://www.vecernji.hr/vijesti/ vlasnica-kozmetickog-salona-nema-veze-s-bandom-pljackasa-280727

Vore, A. (2017, June 11). NYT drops public editor post, creates Reader Center. The San Diego Union-Tribune. https://www.sandiegouniontribune. com/opinion/readers-rep/sd-me-readersrepnb-0611-story.html

Vilović, G. (2010). Ispravak: pokazatelj vjerodostojnosti medija [Correction: An indicator of media credibility]. Medijske studije, 1(1-2), 65-77.

Westerståhl, J. (1983). Objective news reporting: General premises. Communication Research, 10(3), 403-424. https://doi.org/10.1177/00936 5083010003007

Wiesner, V. (2019, February 6). Tužiti medije je biznis, protiv medija vode se 1163 spora, 33 HRT-ova [Suing the media is a business, there are 1,163 lawsuits against the media, HRT have 33 cases]. Večernji list. https://www.vecernji.hr/vijesti/novinarstvo-pred-sudom-protiv-no vinara-pokrenuto-tisuce-tuzbi-1299280 
DRUŠ. ISTRAŽ. ZAGREB

GOD. 30 (2021), BR. 4, STR. 785-806

BRAUTOVIĆ, M.: CORRECTIONS.
Praksa ispravaka u hrvatskim online medijima: između zakonodavstva i tradicije

Mato BRAUTOVIĆ

Odjel za komunikologiju, Sveučilište u Dubrovniku, Dubrovnik, Hrvatska

Ekonomski, tehnološki i društveni trendovi promijenili su model (online) novinarstva tako da su mediji usmjereni na brzinu i količinu objava, što je rezultiralo nižom razinom točnosti u izvještavanju. Da bi mediji zadržali ulogu koju imaju $u$ demokraciji, tom je modelu potrebna odgovarajuća praksa ispravlianja novinarskih pogrešaka. U ovom smo istraživanju uzeli analizu sadržaja kako bismo istražili kako hrvatski online mediji ispravliaju pogreške te kako se njihova praksa ispravaka razlikuje ovisno o vrsti online medija. Rezultati pokazuju da su pogreške radnje ili značenja ( $N=$ 217 ) činile 67,8 \% svih pogrešaka, da je najčešći način ispravljanja pogrešaka objavljivanje neovisne bilješke o pogrešci (ispravci) koja je linkom povezana s originalnom objavom (59\%, $N=188$ ) te da su ispravci bili povezani s neispravljenim objavama u 85,1 \% $(N=159)$ slučajeva. Zaključuje se da je jedina statistički značajna razlika između online izdanja tradicionalnih $\mathrm{i}$ isključivo online medija $u$ načinu imenovanja ispravaka i mjestu njihove objave.

Ključne riječi: online novinarstvo, točnost, ispravci, novinarske pogreške, Hrvatska

\section{(c) (1) $\Theta$}

Međunarodna licenca / International License:

Imenovanje-Nekomercijalno / Attribution-NonCommercial 